\title{
Analysis on the Growth Rhythm and Cold Tolerance of Five-Year Old Eucalyptus benthamiil Plantation for Bioenergy
}

\author{
Aihua Yu1, Tom Gallagher ${ }^{2 *}$ \\ ${ }^{1}$ Department of Forest Engineering, Nanjing Forestry University, Nanjing, China \\ ${ }^{2}$ School of Forestry and Wildlife Sciences, Auburn University, Auburn, AL, USA \\ Email: azy0008@auburn.edu, trgallagher@auburn.edu
}

Received 7 May 2015; accepted 27 July 2015; published 31 July 2015

Copyright (C) 2015 by authors and Scientific Research Publishing Inc.

This work is licensed under the Creative Commons Attribution International License (CC BY). http://creativecommons.org/licenses/by/4.0/

(c) (i) Open Access

\begin{abstract}
A research plot of Eucalyptus benthamii was planted to evaluate this species' ability to supply the emerging bioenergy markets that are developing in the southern U.S. The plot was planted in two different densities to investigate the growth parameters and the cold tolerance. The stand was measured annually through five growing seasons. The results indicated that the growth difference among the young $E$. benthamii was noticeable. For example, the maximum and minimum value of five-year old trees at diameter breast height (DBH) was 27.9 centimeters and 1.27 centimeters; and the maximum and minimum value of tree height was 22.86 meters and 2.44 meters, respectively. The yearly change in DBH and height of $E$. benthamii had significant differences. The average annual survival rates of $E$. benthamii had differences under the two planting densities (1650 trees ha' $\mathrm{h}^{-1}$ and 1237 trees ha-1). The densities also had effects on the height and DBH growth of $E$. benthamii. The average DBH and height of 1650 trees ha-1 plantation were 11.18 centimeters and 15.03 meters, and the average DBH and height of 1237 trees ha-1 $^{-1}$ plantation were 13.46 centimeters and 16.28 meters. The volume per hectare of 1650 trees ha-1 and 1237 trees ha-1 plantation were 111.45 cubic meters and $\mathbf{1 0 1 . 1 5}$ cubic meters, respectively. Average diameter growth was almost 2.54 centimeters per year and average height growth was over 3 meters. E. benthamii plantations were considered tolerant to $\mathbf{- 7 . 4}$ degrees Celsius and a cold spell during early 2014 (-11.3 degrees Celsius for two consecutive nights) killed the plantation. The growth of $E$. benthamii also varied depending on surrounding conditions. The difference in growth of row seven versus row one was a good example. The reason probably was that row seven was adjacent to a loblolly pine plantation and row one was next to an open field.
\end{abstract}

\footnotetext{
"Corresponding author.
} 
Keywords

Eucalyptus benthamii, Growth Parameters, Bioenergy, Cold Tolerance

\section{Introduction}

Biomass is a primary source of food energy, which includes plant biomass (or phytomass) and animal biomass (Abbasi \& Abbasi, 2010). Biomass energy was the first form of energy (except food) that humans learned to use. Many forest species are considered for bioenergy plantations, including pine, cottonwood, sweetgum, and other hardwood species. Eucalyptus is one genus with tremendous bioenergy potential (Dougherty \& Wright, 2010). Commercial Eucalyptus plantations, as a source of logs for pulp, wood chips and fuel wood, have great potential (Brown, 2000) and several forest products companies have established large eucalypt plantations in South America (Spinelli et al., 2009).

The main motivation to explore the potential for bioenergy production from Eucalyptus is the need for a biomass that is fast growing, relatively low cost and highly productive (Gonzalez et al., 2011). These characteristics make Eucalyptus ideal for bioenergy forest plantations in specific parts in the southern United States (Dougherty \& Wright, 2010). Economically important species of eucalyptus that can adapt to harsh climatic conditions are limited, but $E$. benthamii and $E$. dunnii stand out among these species. They offer the possibility to adapt to climate change, timber production and quality (BORÉM, 2007). Recent tests indicate that $E$. benthamii seems cold hearty enough to use in the southern United States and to be considered for biomass plantations (Dougherty \& Wright, 2012).

Eucalyptus benthmii belongs to Symphomyrtus, Maidenaria group, which grows as a tall tree to 35 or 40 meters (115 or 131 feet) high, with a trunk diameter attaining 1.5 meters (4.9 feet) (Douglas et al., 2006). The bark is smooth and white, and peels away in ribbons (Doug \& Lyn, 1998). The ability of Eucalyptus benthamii to grow very quickly is the most desirable as Dougherty and Wright (2012) envisaged that the annual demand of eucalyptus could be about 20 million tons per year by the year 2022 .

Any plantation forest in the process of its formation and development has to go through different growth stages, and each stage has their own characteristics. So it is necessary to understand and master the species biological characteristics and ecological habits in order to better manage the plantation forest (Su et al, 2005). However, little is known about the growth rhythm of E. benthamii planted in different density and its suitability to the diverse sites it could potentially be established in the U.S. In this paper, we report the 5-year growth rhythm and survival of two densities planted at the Solon Dixon Forestry Center located between Andalusia and Brewton, Alabama, USA. We also report the relationship between the growth rates of Eucalyptus benthamii and the temperatures.

\section{Material and Methods}

\subsection{Study Site}

The study area is located at the Solon Dixon Forestry Center (SDFC) between Andalusia and Brewton, Alabama $\left(31^{\circ} 18^{\prime} \mathrm{N} 86^{\circ} 29^{\prime} \mathrm{W}\right)(31.309,-86.479)$. SDFC is a diverse 5300 acre "working forest". The topography of SDFC consists of upper coastal plain rolling hills with mostly gentle slopes. The average elevation is 89.9 meters. Local soil type is clay loam. The climate in this area is characterized by hot, humid summers and generally mild to cool winters, which has a humid subtropical climate.

The average temperature for the year in this area is $18.3^{\circ} \mathrm{C}\left(65.0^{\circ} \mathrm{F}\right)$. The warmest month, on average, is July with an average temperature of $26.8^{\circ} \mathrm{C}\left(80.3^{\circ} \mathrm{F}\right)$. The coolest month on average is January, with an average temperature of $8.9^{\circ} \mathrm{C}\left(48.1^{\circ} \mathrm{F}\right)$. The highest recorded temperature is $40.6^{\circ} \mathrm{C}\left(105.0^{\circ} \mathrm{F}\right)$, which was recorded in June. The lowest recorded temperature is $-17.8^{\circ} \mathrm{C}\left(0.0^{\circ} \mathrm{F}\right)$, which was recorded in January. The average amount of precipitation for the year in this area is $1508.8 \mathrm{~mm}$ (59.4"). The month with the most precipitation on average is March with $162.6 \mathrm{~mm}(6.4 ")$; the month with the least precipitation on average is October with $71.1 \mathrm{~mm}(2.8 ")$. There is an average of 101.0 days of precipitation, with the most precipitation occurring in July with 13.0 days and the least precipitation occurring in October with 5.0 days (All of the data from: Climate Summary for An- 
dalusia, Alabama).

\subsection{Sample Set and Survey Methods}

The Eucalyptus benthamii plantation was planted on March 31, 2009. The Arborgen Company provided seedlings. The site had chemical site preparation with glyphosate. Some mowing occurred during the first summer and two additional applications of glyphosate were applied to keep weeds and grasses down around the seedlings.

There were two test plots of almost the same acreage $\left(0.25 \mathrm{ha}^{-1}\right)$ planted with different densities. The initial densities of the test plots for Eucalyptus benthamii were 1650 trees ha ${ }^{-1}$ and 1237 trees $^{-1}{ }^{-1}$, respectively. There were a total of seven rows for each test plot, 3.66 meters between rows, 1.8 and 2.4 meters between seedlings. The first row was near an open field and the seventh row was adjacent to a Loblolly pine plantation.

Data were obtained from all the planted trees and measurements were taken of the diameter at breast height (DBH) (diameter measured at base of tree for first two measurements) using a measuring tape, and total height (Ht) of each tree, using a digital hypsometer for five annual measurements (Apr. 2, 2010; Jan. 7, 2011; Dec. 14, 2011; Feb. 25, 2013 and Feb. 3, 2014). The $5^{\text {th }}$ measurement was the last measurement because a heavy freeze during early 2014 had killed the trees. The volume with bark (V) was derived using equations.

\subsection{Analysis Methods}

The volume of timber is the most important index to measure the growth of trees. As a commercial plantation, the volume of Eucalyptus is one of the nuclear issues to measure the effect of their management (Fan et al., 2013). The volume of Eucalyptus is calculated by the following formula (Yang et al., 2009).

$$
\begin{gathered}
\mathrm{V}_{\text {Eucalyptus individual volume }}=0.0004 \mathrm{D}^{2} \mathrm{H} \\
\mathrm{V}_{\text {Eucalyptus volume }}=\mathrm{V}_{\text {Eucalyptus individual volume }} \times \mathrm{P}_{\text {stand density }}
\end{gathered}
$$

$\mathrm{V}$ is the volume (cubic meters, $\mathrm{m}^{3}$ );

$\mathrm{D}$ is the diameter at breast height $(\mathrm{cm})$;

$\mathrm{H}$ is the tree height (m);

$\mathrm{P}$ is the stand density (trees ha ${ }^{-1}$ ).

Data were keyed into Microsoft Excel 2010 and the main growth parameters (Ht and DBH) were analyzed for single-factor analysis of variance (at $p<0.05$ ) using SPSS 18.0 statistical software. After finding significance, a test using least significant difference methods (LSD) for multiple comparisons was completed. A third test using a paired samples test (T-test) for statistical data analysis was also performed.

\section{Results}

After five growing seasons, there are clear differences between the two plantation densities regarding $\mathrm{DBH}$, tree heights, survival rate and other characteristics (Table 1, Figure 1).

The results from the ANOVA at age five years showed that the growth of trees (DBH and height) in the two densities were a significant difference (Table 2, paired samples test of DBH and height in two densities, 1650 trees ha ${ }^{-1}$ and 1237 trees $_{\text {ha }}{ }^{-1}$ ).

\begin{tabular}{|c|c|c|c|c|c|c|c|c|}
\hline \multirow{2}{*}{ Age/a } & \multicolumn{4}{|c|}{1650 trees ha $^{-1}$} & \multicolumn{4}{|c|}{1237 trees ha $^{-1}$} \\
\hline & $\mathrm{DBH} / \mathrm{cm}$ & $\mathrm{Ht} / \mathrm{m}$ & $\mathrm{V} / \mathrm{m}^{3}$ & Survival Rate/\% & $\mathrm{DBH} / \mathrm{cm}$ & $\mathrm{Ht} / \mathrm{m}$ & $\mathrm{V} / \mathrm{m}^{3}$ & Survival rate/\% \\
\hline 1 & 2.54 & 1.55 & & 86.4 & 2.54 & 1.49 & & 87.9 \\
\hline 2 & 5.33 & 3.54 & & 82.7 & 5.59 & 3.66 & & 81.6 \\
\hline 3 & 6.60 & 7.07 & 0.0123 & 82.1 & 7.62 & 8.05 & 0.0187 & 73.3 \\
\hline 4 & 9.90 & 10.18 & 0.0399 & 81.4 & 11.43 & 11.03 & 0.0576 & 73.0 \\
\hline 5 & 11.18 & 15.03 & 0.0752 & 80.7 & 13.46 & 16.28 & 0.1180 & 69.3 \\
\hline
\end{tabular}

Table 1. Growth parameters of E. benthamii in different ages and densities.

Note: 1) All the data are average data. 2) Diameter measured at the base of tree for first two years. 
Table 2. The results of paired samples test of DBH and height in two densities.

\begin{tabular}{|c|c|c|c|c|c|c|c|c|}
\hline & \multicolumn{8}{|c|}{ Paired Differences } \\
\hline & \multirow{2}{*}{ Mean } & \multirow{2}{*}{$\begin{array}{c}\text { Std. } \\
\text { Deviation }\end{array}$} & \multirow{2}{*}{ Std. Error Mean } & \multicolumn{2}{|c|}{$\begin{array}{l}\text { 95\% Confidence Interval of } \\
\text { the Difference }\end{array}$} & \multirow{2}{*}{$\mathrm{t}$} & \multirow{2}{*}{ df } & \multirow{2}{*}{$\begin{array}{c}\text { Sig } \\
\text { (2-tailed) }\end{array}$} \\
\hline & & & & Lower & Upper & & & \\
\hline DD1-DD2 ${ }^{*}$ & -0.99229 & 1.49958 & 0.25348 & -1.50741 & -0.47716 & -3.915 & 34 & 0.000 \\
\hline DH1-DH2 ${ }^{*}$ & -0.62629 & 1.23265 & 0.20836 & -1.04972 & -0.20286 & -3.006 & 34 & 0.005 \\
\hline
\end{tabular}

Note: DD1, DH1 were the DBH and height of the 1650 trees ha ${ }^{-1}$. DD2, DH2 were the DBH and height of the 1237 trees ha $^{-1}$. $^{*}$ indicated statistically difference at 0.05 level.

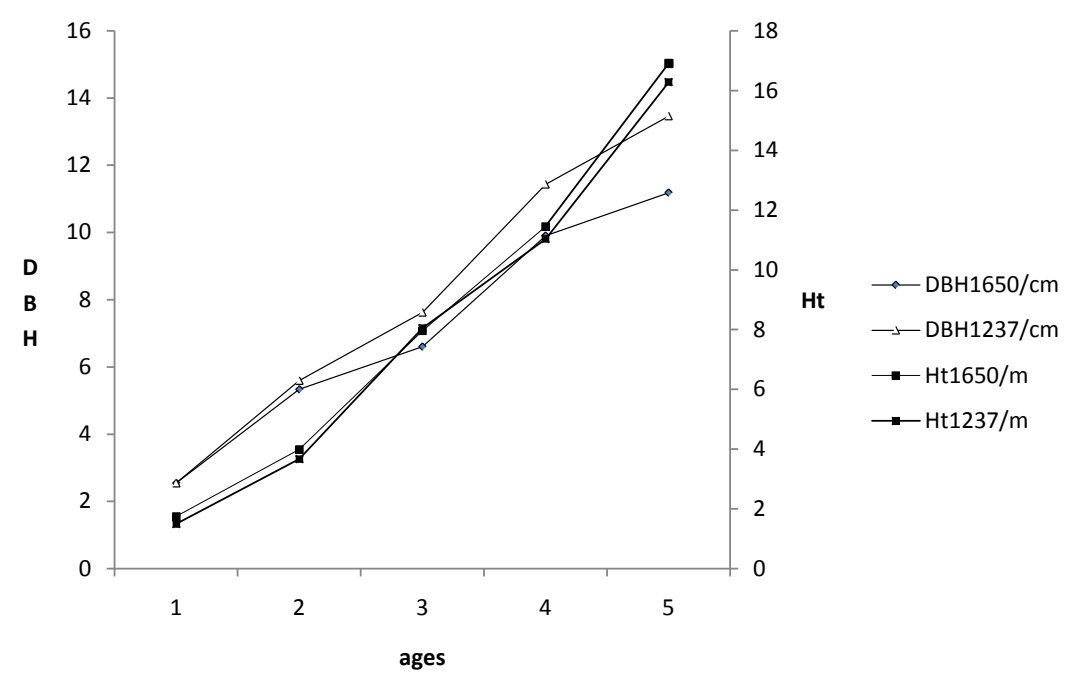

Figure 1. DBH and Height changes under different ages and densities.

The plantation with a density of 1237 trees $^{-1} \mathrm{a}^{-1}$ had a higher average diameter and height (13.46 centimeters and 16.28 meters) than the trees planted at 1650 trees ha ${ }^{-1}$ (11.18 centimeters and 15.03 meters). As to be expected, the density of 1237 trees $^{-1}{ }^{-1}$ had higher volume per tree than the density of 1650 trees ha $^{-1}$, but had a lower volume per hectare. The volume per hectare of 1650 trees ha ${ }^{-1}$ and 1237 trees ha ${ }^{-1}$ plantation were 111.45 cubic meters and 101.15 cubic meters, respectively.

The mean annual survival rate was quite different between the two densities; the density of 1650 trees ha $^{-1}$ was higher (Table 1). That was the true survival rate of the Eucalyptus plantation without any human intervention and probably mainly affecting the suppressed trees.

The results also showed that there were some differences between different rows, especially between the first row and the seventh row regarding the DBH and heights (Table 3, Figure 2). The average DBH and height of the first row were 14.48 centimeters and 14.81 meters, which were higher than the seventh row's, whose average DBH and height were 6.6 centimeters and 10.88 meters. The survival rate of the first row was $82 \%$, higher than the seventh row's, which was $67.3 \%$. The reason probably was that the seventh row Eucalyptus were affected by the adjacent loblolly pine trees, but the first row Eucalyptus were near open fields which allowed for full sunshine.

The DBH and tree height between the first row and the seventh rows had significant difference under 1237 trees ha ${ }^{-1}$ density (Table 4). The trees of DBH and height yearly change also had significant difference (Table 5). The average at the base of diameter growth was 2.95 centimeters between the first year and the second year, maximum growth was 10.2 centimeters and minimum growth was -0.12 centimeters. The average at $\mathrm{DBH}$ growth was 3.53 centimeters between the third year and the fourth year. Diameter growth could not be compared between years two and three because the diameter measurement location moved from the base to DBH. The average trees height was 2.03 meters between the first year and the second year, 3.65 meters growth between the second and the third year, and 3.21 meters growth between the third and the fourth year. 
Table 3. Growth parameters of E. benthamii in different rows, ages and densities (Diameter measured at the base of tree at first two years).

\begin{tabular}{|c|c|c|c|c|c|c|c|c|c|c|c|}
\hline \multirow{2}{*}{$\begin{array}{l}\text { Age } \\
\text { Row }\end{array}$} & \multicolumn{6}{|c|}{$\mathrm{DBH} / \mathrm{cm}$} & \multicolumn{5}{|c|}{ Tree Height/m } \\
\hline & & 1 & 2 & 3 & 4 & 5 & 1 & 2 & 3 & 4 & 5 \\
\hline \multirow{10}{*}{$\begin{array}{l}1650 \\
\text { Tree } \\
\text { ha }^{-1}\end{array}$} & 1 & 2.54 & 4.82 & 6.35 & 10.67 & 12.45 & 1.46 & 2.90 & 5.70 & 9.03 & 13.17 \\
\hline & 2 & 2.03 & 4.82 & 6.60 & 10.16 & 11.68 & 1.10 & 2.90 & 6.58 & 9.72 & 14.60 \\
\hline & 3 & 2.80 & 5.84 & 7.11 & 9.91 & 11.68 & 1.55 & 3.44 & 7.28 & 10.49 & 16.12 \\
\hline & 4 & 2.80 & 6.35 & 7.87 & 11.68 & 13.46 & 1.74 & 4.05 & 8.38 & 11.70 & 17.28 \\
\hline & 5 & 2.80 & 6.10 & 7.37 & 10.16 & 11.43 & 1.83 & 4.08 & 8.35 & 11.16 & 16.21 \\
\hline & 6 & 2.29 & 5.84 & 7.37 & 10.67 & 11.94 & 1.65 & 4.18 & 8.60 & 11.55 & 17.03 \\
\hline & 7 & 2.54 & 4.06 & 3.56 & 5.59 & 6.35 & 1.61 & 3.11 & 4.72 & 7.38 & 10.82 \\
\hline & Average & 2.54 & 5.33 & 6.60 & 9.91 & 11.18 & 1.55 & 3.54 & 7.07 & 10.18 & 15.02 \\
\hline & $\begin{array}{l}\text { Volume per } \\
\text { Tree/m } \mathrm{m}^{3}\end{array}$ & & & 0.0123 & 0.0399 & 0.0837 & & & & & \\
\hline & Volume $/ \mathrm{m}^{3} \cdot \mathrm{ha}^{-1}$ & & & 17.540 & 53.590 & 111.45 & & & & & \\
\hline \multirow{10}{*}{$\begin{array}{l}1237 \\
\text { Tree } \\
\text { Ha }^{-1}\end{array}$} & 1 & 3.30 & 7.62 & 9.91 & 14.99 & 17.53 & 1.80 & 4.11 & 9.02 & 12.65 & 17.37 \\
\hline & 2 & 2.29 & 5.84 & 7.37 & 10.92 & 13.21 & 1.22 & 3.60 & 8.14 & 11.0 & 16.63 \\
\hline & 3 & 2.80 & 6.60 & 7.87 & 11.18 & 13.21 & 1.58 & 3.93 & 8.17 & 10.82 & 16.33 \\
\hline & 4 & 2.54 & 5.59 & 7.87 & 11.68 & 14.22 & 1.52 & 3.87 & 8.63 & 11.55 & 17.00 \\
\hline & 5 & 2.54 & 6.35 & 8.89 & 12.95 & 14.99 & 1.52 & 4.27 & 9.72 & 13.08 & 17.13 \\
\hline & 6 & 2.29 & 5.08 & 8.13 & 12.12 & 13.97 & 1.52 & 3.66 & 8.60 & 11.87 & 18.41 \\
\hline & 7 & 1.78 & 2.79 & 3.05 & 5.33 & 7.62 & 1.21 & 2.10 & 4.08 & 6.19 & 11.09 \\
\hline & Average & 2.54 & 5.59 & 7.62 & 11.43 & 13.46 & 1.49 & 4.27 & 8.05 & 11.03 & 16.28 \\
\hline & $\begin{array}{l}\text { Volume per } \\
\text { Tree/m }{ }^{3}\end{array}$ & & & 0.0187 & 0.0576 & 0.1180 & & & & & \\
\hline & Volume $/ \mathrm{m}^{3} \cdot \mathrm{ha}^{-1}$ & & & 16.886 & 52.01 & 101.15 & & & & & \\
\hline
\end{tabular}

Table 4. Results of paired samples test of DBH and height between row 1 and row 7.

\begin{tabular}{|c|c|c|c|c|c|c|c|c|}
\hline & \multicolumn{8}{|c|}{ Paired Differences } \\
\hline & \multirow{2}{*}{ Mean } & \multirow{2}{*}{$\begin{array}{c}\text { Std. } \\
\text { Deviation }\end{array}$} & \multirow{2}{*}{ Std. Error Mean } & \multicolumn{2}{|c|}{$\begin{array}{l}\text { 95\% Confidence Interval of } \\
\text { the Difference }\end{array}$} & \multirow{2}{*}{$\mathrm{t}$} & \multirow{2}{*}{ df } & \multirow{2}{*}{$\begin{array}{c}\text { Sig } \\
\text { (2-tailed) }\end{array}$} \\
\hline & & & & Lower & Upper & & & \\
\hline DD11-DD17 & 2.946 & 2.64497 & 1.18287 & -0.33817 & 6.23017 & -2.491 & 4 & 0.067 \\
\hline DH11-DH17 & 0.924 & 1.11838 & 0.50016 & -0.46466 & 2.31266 & -1.847 & 4 & 0.138 \\
\hline DD21-DD27 ${ }^{*}$ & 6.556 & 3.51130 & 1.57030 & 2.19614 & 10.9159 & 4.175 & 4 & 0.014 \\
\hline DH21-DH27* & 4.056 & 2.63183 & 1.17699 & 0.78815 & 7.32385 & 3.446 & 4 & 0.026 \\
\hline
\end{tabular}

Note: DD11, DH11 were the DBH and height of row 1 under the 1650 trees ha ${ }^{-1}$. DD17, DH17 were the DBH and height of row 7 under the 1650 trees $\mathrm{ha}^{-1}$. DD21, DH21 were the DBH and height of row 1 under the 1237 trees ha ${ }^{-1}$. DD27, DH27 were the DBH and height of row 7 under the 1237 trees $^{-1}{ }^{-1}$. indicated statistically difference at 0.05 level.

This plantation indicated that the $E$. benthamii could tolerate the -7.4 degree $C$ in 2011 , but a cold spell during early 2014 (-11.3 degrees Celsius for two consecutive nights) killed the plantation. The correlations of the growth parameters with temperatures were analyzed; the results showed that there were no significant correlations between the growth parameters of E. benthamii and temperatures (Table 6). The growing of Eucalyptus benthamii wasn't effected by temperatures, but limited by the lowest temperature. While the trees might handle 
Table 5. Results of paired samples test of DBH and height yearly change.

\begin{tabular}{|c|c|c|c|c|c|c|c|c|}
\hline & \multicolumn{8}{|c|}{ Paired Differences } \\
\hline & \multirow{2}{*}{ Mean } & \multirow{2}{*}{$\begin{array}{c}\text { Std. } \\
\text { Deviation }\end{array}$} & \multirow{2}{*}{ Std. Error Mean } & \multicolumn{2}{|c|}{$\begin{array}{l}\text { 95\% Confidence Interval of } \\
\text { the Difference }\end{array}$} & \multirow{2}{*}{$\mathrm{t}$} & \multirow{2}{*}{ df } & \multirow{2}{*}{$\begin{array}{c}\text { Sig } \\
\text { (2-tailed) }\end{array}$} \\
\hline & & & & Lower & Upper & & & \\
\hline D12-D23* & -1.5884 & 0.85932 & 0.04542 & -1.6777 & -1.4991 & 34.974 & 357 & 0.00 \\
\hline D23-D34* & 1.35449 & 1.08848 & 0.05753 & 1.2413 & 1.4676 & 23.545 & 357 & 0.00 \\
\hline D12-D34* & -0.2339 & 0.70328 & 0.03717 & -0.3070 & -0.16082 & -6.293 & 357 & 0.00 \\
\hline H12-H23* & -17.687 & 6.99071 & 0.36947 & -18.413 & -16.960 & -47.871 & 357 & 0.00 \\
\hline H23-H34* & 13.807 & 10.7252 & 0.56684 & 12.6925 & 14.9220 & 24.358 & 357 & 0.00 \\
\hline H12-H34* & -0.3879 & 6.28426 & 0.33213 & -4.5328 & -3.2264 & -11.681 & 357 & 0.00 \\
\hline
\end{tabular}

D12 means the diameter yearly change between the first year and the second year. H12 means the trees height yearly change between the first year and the second year. ${ }^{*}$ indicated statistically difference at 0.05 level.

Table 6. Relationship of growth parameters and temperature.

\begin{tabular}{|c|c|c|c|c|c|c|}
\hline \multirow{2}{*}{ Time } & \multicolumn{3}{|c|}{ Temperature $\left({ }^{\circ} \mathrm{C}\right)$} & \multirow{2}{*}{ Survival \% } & \multirow{2}{*}{$\begin{array}{l}\text { DBH Growth } \\
\text { (cm) }\end{array}$} & \multirow{2}{*}{$\begin{array}{l}\text { Height Growth } \\
\text { (m) }\end{array}$} \\
\hline & High & Low & Average & & & \\
\hline March 31, 2009-April 2, 2010 & 37.2 & -7.4 & 16.3 & 86.9 & 2.54 & 1.52 \\
\hline April 3, 2010-Jan 7, 2011 & 40.3 & -7.4 & 20.2 & 82.7 & 1.92 & 2.39 \\
\hline Jan 8, 2011-Dec 14, 2011 & 39.4 & -7.2 & 18.9 & 82.1 & * & 3.65 \\
\hline Dec 15, 2011-Feb 25, 2013 & 35.8 & -6.5 & 17.4 & 81.4 & 3.56 & 3.04 \\
\hline Feb 26, 2013-Feb 3, 2014 & 34.5 & -11.3 & 17.5 & 80.7 & 1.65 & 5.05 \\
\hline
\end{tabular}

NOTE: Diameter measured at the base of tree at first two years. ${ }^{*}$ The second measured diameter at the base of tree, but the third measured at the breast height, so they couldn't compare the growth.

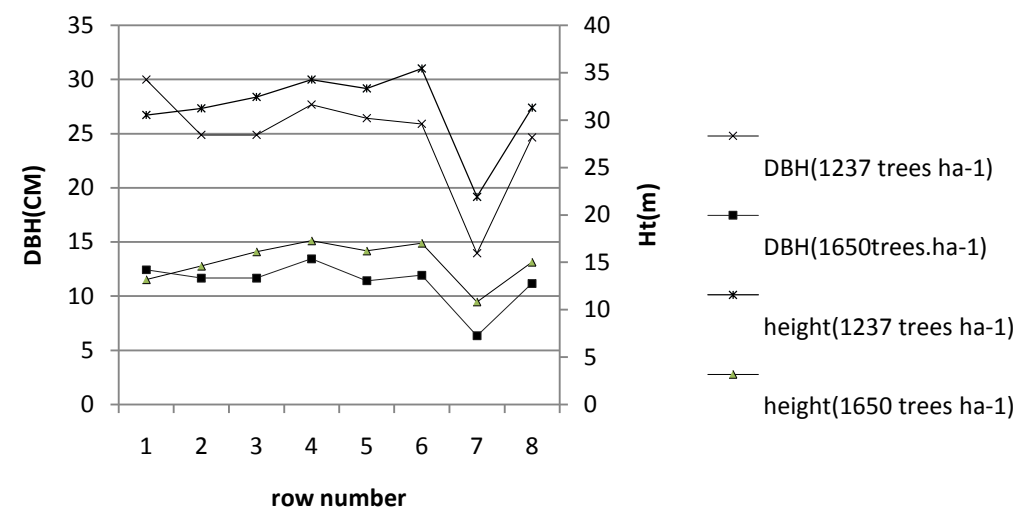

Figure 2. DBH and Height of different rows with two densities. Note: Row 8 is average data across all rows.

a little while under the -7.4 degrees Celsius, any extended period will kill the plantation.

\section{Discussion}

Tree growth is mainly effected by three factors: genotype, management and environment (Balozi et al., 2010). Our study showed that the even with the same genotype and management, growth varied depending on the environment. For example, the growth had great differences between the seventh row and the first row. The growth of the first row was better than the seven throw. And the survival in row seven was lower than in the others, especially lower than in row one. The probable reason was that row seven was adjacent to the loblolly 
pine plantation, however row one was near open fields. It also showed that the full sunshine favors the growth of E. benthamii.

In this study, the results also showed that tree size (height and DBH) of E. Benthamii was significantly influenced by the densities. The volume of E. benthamii in different densities also showed differences. The lower density plantation (1237 tree ha $^{-1}$ ) compared to higher density (1650 tree ha ${ }^{-1}$ ) had higher volume per tree, but had lower volume per hectare. This indicates that the suitably high density is better than the low density as the $E$. benthamii plantation for bioenergy. If the plantation was established for a pulpwood market, the lower density configuration might be more desirable.

As we all know, Eucalyptus is a fast growing species and E. benthamii plantation was a good example. Diameter growth averaged almost 2.54 centimeters per year and height growth was over 3 meters, but there was noticeable variability between individuals. The maximum and minimum value of five years old trees diameter breast height $(\mathrm{DBH})$ was 27.9 centimeters and 1.27 centimeters, as the maximum and minimum value of tree height was 22.86 meters and 2.44 meters, respectively. This indicates the importance good seedling selection and more work is needed to strengthen plantation management to reduce variability. DBH and height of $E$. benthamii yearly change had significant difference. The growth rhythm observed in this plantation are similar to those found by Chen (2007) in Eucalyptus. dunnii plantations.

Dougherty and Wright (2010) reported that Eucalypt benthamii appeared to have enough cold tolerance to be considered for use in biomass plantations in southeastern United States. These tests showed that E. benthamii appeared to have enough cold tolerance and our test plantation also showed this potential. The E. benthamii plantation could tolerant the -7.4 degrees C in 2011, but couldn't tolerant the -11.3 degrees C during early 2014 $\left(-11.3^{\circ} \mathrm{C}\right.$ for two consecutive nights). The cold spell killed the plantation. Our studies also showed that the growth and the survival of E. benthamii plantation didn't have correlations with temperatures, except the lower limit temperature. This indicated that the average temperatures had no influence of the growing of E. benthamii, but there was a limit temperature.

The growth of $E$. benthamiiis effected by climate, physical and chemical properties of soil, and different fertilizer methods, which could all be additional research in the future.

\section{Conclusion}

Some Eucalyptus species have shown very attractive characteristics for growing fast and bole straightness. In this study, E. benthamii has shown this potential; diameter growth averaged almost 2.54 centimeters per year and height growth was over 3 meters per year. Our study also showed that the growth difference among the young $E$. benthamii was great. Some of the growth parameters such as DBH and height of E. benthamii yearly change had significant difference. The densities had great effects on the height and DBH growth of E. benthamii. The growth of DBH and height had significant difference of different densities, and the volume of E. benthamii also difference. E. benthamii plantations were considered tolerant to -7.4 degrees $\mathrm{C}$ and the limited temperatures probably was -11.3 degrees $\mathrm{C}$ because the cold spell $\left(-11.3^{\circ} \mathrm{C}\right.$ for two consecutive nights) killed the plantation. Different environments affected the growth of $E$. benthamii. The growth between the row seven and the row one was a good example.

\section{References}

Abbasi, T., \& Abbasi ,S. A. (2010). Biomass Energy and the Environmental Impacts Associated with Its Production and Utilization. Renewable and Sustainable Energy Reviews, 14, 919-937. http://dx.doi.org/10.1016/j.rser.2009.11.006

Balozi, K. B., Kimani, G., Senelwa, K., Etiegni, L., Mbelase, A., \& Muchiri, M. (2010). Five Year Growth and Survival of Eucalyptus Hybrid Clones in Coastal Kenya. JMHT, XVI, 1-9.

BORÉM, A. (2007). Biotecnologiaflorestal. Viçosa: Suprema.

Brown, C. (2000). Global Forest Products Outlook Study: The Future Supply of Wood from Plantations. Rome: Forestry Policy and Planning Division, FAO.

Chen, J. Z. (2007). The Growth Rhythm of Young Plantations of Eucalyptus dunnii. Journal of Fujian College of Forestry, 27, 88-91.

Dougherty, D., \& Wright, J. (2010). Financial Evaluation of Eucalypt Bioenergy Plantation in the Southeastern United States. Forest Landowner, 69, 26-30.

Doug, B., \& Lyn, M. L. (1998). Ecology of Sydney Plant Species: Part 6, Dicotyledon Family Myrtaceae. Cunninghamia, 5, 809-987. 
Dougherty, D., \& Wright, J. (2012). Silviculture and Economic Evaluation of Eucalypt Plantations in the Southern US. BioResources, 7, 1194-2001.

Douglas, B. J., Brooker, M. I. H., Chippendale, G. M., \& McDonald, M.W. (2006). Forest Trees of Australia. Collingwood, VA: CSIRO Publishing, 396.

Fan, W. B., Zhao, C. J., Lin, Z., \& Chen H. (2013). Growth Characteristics of Eucalyptus Plantation and Their Responses to Climate Environment in Western Hainan Island. Forest Resources Management, 4, 77-82.

Gonzalez, R., Treasure, T., Phillips, R., Jameel, H., Saloni, D., Abt, R., \& Wright, J. (2011). Converting Eucalyptus Biomass into Ethanol: Financial and Sensitivity Analysis in a Co-Current Dilute Acid Process. Part II. Biomass and Bioenergy, 35, 767-772. http://dx.doi.org/10.1016/j.biombioe.2010.10.025

Spinelli, R., Ward, S. M., \& Owende, P. M., (2009). A Harvest and Transport Cost Model for Eucalyptus spp. Fast-Growing Short Rotation Plantations. Biomass and Bioenergy, 33, 1265-1270. http://dx.doi.org/10.1016/j.biombioe.2009.05.010

Su, H. J., Zhao, F., \& Li, H. G., (2005). Growth Rules of Pinus sylvestris var. Mongolica on Sandy Land. Protection Forest Science and Technology, 68, 12-13.

Yang, Z. J., Xu , D. P., Chen, W. P., Huang, L. J., Li, S. J., \& Chen, Y. (2009). Growth Effect of Eucalyptus-Acacia Mixed Plantation in South China. Chinese Journal of Applied Ecology, 20, 2339-2344. 